\title{
IMPLEMENTASI PRODUK PEMBIAYAAN USAHA MIKRO KECIL MENENGAH (UMKM) (Studi Pada PT. Bank Syariah Mandiri Cabang Pembantu Panyabungan)
}

\author{
Fadli \\ Institut Agama Islam Negeri Padangsidimpuan \\ Jalan T. Rizal Nurdin Km. 4,5 Sihitang, Padangsidimpuan \\ Email: fadligodenboy31@gmail.com
}

\begin{abstract}
Abstrak,
Usaha Mikro Kecil Menengah (UMKM) adalah ekonomi yang berbasis pada kekuatan ekonomi rakyat. Ekonomi rakyat adalah kegiatan ekonomi atau usaha yang dilakukan oleh rakyat kebanyakan yang dengan secara swadaya mengelola sumber daya ekonomi apa saja yang dapat diusahakan dan dikuasainya. UMKM meliputi sektor pertanian, peternakan, kerajinan, makanan, yang bertujuan terutama untuk memenuhi kebutuhan dasar dan keluarga tanpa harus mengorbankan kepentingan masyarakat lainnya. Pada segmen UMKM, Bank Syariah Mandiri memiliki program pembiayaan yang disebut warung mikro, dengan tujuan untuk mendorong kinerja atau mengembangkan usaha nasabah melalui pembiayaan. Adapun tujuan penelitian ini adalah untuk mengetahui bagaimana implementasi produk penyaluran dana untuk segmen UMKM pada PT. Bank Syariah Mandiri Cabang Pembantu Panyabungan. Penelitian ini menggunakan metode kualitatif deskriptif, dengan sumber data primer dari karyawan PT. Bank Syariah Mandiri Cabang Pembantu Panyabungan yang di kumpulkan melalui observasi, wawancara dan dokumentasi serta dianalisa menggunakan pendekatan trianggulasi. Hasil penelitian menunjukkan bahwa pembiayaan UMKM PT. Bank Syariah Mandiri Cabang Pembantu Panyabungan dilakukan dengan menggunakan akad murabahah.
\end{abstract}

Kata Kunci: Implementasi, Produk, Pembiayaan

\begin{abstract}
,
Micro, Small and Medium Enterprises are economies based on the economic power of the people. People's economy is an economic or business activity carried out by the common people who independently manage any economic resources that can be cultivated and controlled by them, including the agriculture, animal husbandry, handicraft, food sectors, which primarily aim to meet their basic needs and their families without sacrificing other people's interests. In the Micro, Small and Medium Enterprises segment (MSMEs), Bank Syariah Mandiri has a financing program called Warung Mikro, with the aim of encouraging performance or developing the customer's business through financing. The purpose of this research is to know how the implementation of fund distribution products for the Micro, Small and Medium Enterprises (MSMEs) segment of PT. Bank Syariah Mandiri Branch of Panyabungan. This research uses descriptive qualitative method, with primary data sources from employees of PT. Bank Syariah Mandiri Branch of Panyabungan which was collected through observation, interviews and documentation and analyzed using the triangulation approach. The result of the research showed that Micro, Small and Medium Enterprises PT. Bank Syariah Mandiri Branch of Panyabungan is done using a murabahah contract.
\end{abstract}

Keywords: Implementation, Products, Financing 


\section{PENDAHULUAN}

Pada pasal 1 ayat (1) Undang-Undang Nomor 21 Tahun 2008 Tentang Perbankan Syariah menyatakan perbankan syariah adalah segala sesuatu yang mencakup kelembagaan, kegiatan, usaha, serta cara dan proses dalam melaksanakan kegiatan usahanya. Menurut jenisnya terdiri atas Bank Umum Syariah dan Bank Pembiayaan Rakyat Syariah. Usaha kecil menengah adalah ekonomi yang berbasis pada kekuatan ekonomi rakyat. Ekonomi rakyat adalah kegiatan ekonomi atau usaha yang dilakukan oleh rakyat kebanyakan (populer) yang dengan secara swadaya mengelola sumberdaya ekonomi apa saja yang dapat diusahakan dan dikuasainya, UMKM meliputi sektor pertanian, peternakan, kerajinan, makanan, yang bertujuan terutama untuk memenuhi kebutuhan dasarnya dan keluarganya tanpa harus mengorbankan kepentingan masyarakat lainnya (Muhammad, 2005).

Terkait dengan asas operasional bank syariah berdasarkan Undang-undang No 21 Tahun 2008, disebutkan bahwa perbankan syariah dalam melaksanakan kegiatan usahanya berdasarkan prinsip syariah, demokrasi ekonomi, dan prinsip kehati-hatian. Dan memiliki tujuan yaitu menunjang pelaksanaan pembangunan nasional dalam rangka meningkatkan keadilan, dan pemerataan kesejahteraan rakyat (Yaya, dkk,2009). Dalam pencapain tujuan tersebut, Bank Syariah Mandiri memiliki visi dan misi yakni, Bank Syariah Mandiri terpercaya pilihan mitra usaha. Dan misinya adalah mewujudkan pertumbuhan dan keuntungan yang berkesinambungan. Mengutamakan penghimpunan dana konsumen dan penyaluran pembiayaan segmen Usaha Mikro Kecil Menengah, mengembangkan nilai-nilai syariah universal.

Pada segmen Usaha Mikro Kecil Menengah (UMKM), Bank Syariah Mandiri memiliki program pembiayaan yang disebut warung mikro. Pembiayaan warung mikro diberikan kepada nasabah pada sektor usaha mikro dengan tujuan untuk mendorong kinerja atau mengembangkan usaha nasabah yang diberikan pembiayaan. Pembiayaan Usaha Mikro adalah kegiatan ekonomi rakyat berskala kecil dan bersifat tradisional dan informal dalam arti belum terdaftar, belum tercatat dan belum berbadan hukum (Lubis,2017). Perkembangan pembiayaan yang disalurkan oleh Bank Syariah Mandiri dan Unit Usaha Syariah ke UMKM terus mengalami peningkatan dari 2010-2013, akan tetapi 2014 mengalami penurunan, sebagaimana yang terdapat pada tabel 1 berikut ini: 
Tabel 1.

Perkembangan Tingkat Pembiayaan Usaha Mikro Kecil Menengah (UMKM)

Pada Bank Syariah Mandiri Tahun 2010-2014

Dalam Milyar Rupiah

\begin{tabular}{|l|l|l|}
\hline No & Tahun & Tingkat Pembiayaan \\
\hline 1 & 2010 & 23.968 \\
\hline 2 & 2011 & 36.727 \\
\hline 3 & 2012 & 44.755 \\
\hline 4 & 2013 & 50.460 \\
\hline 5 & 2014 & 49.133 \\
\hline
\end{tabular}

Sumber :www.Bank Syariah. Laporan keuangan

Dalam menyalurkan dana, secara garis besar besar produk pembiayaan syariah terbagi ke dalam empat katagori yang dibedakan berdasarkan tujuan penggunaanya, yaitu: pembiayaan dengan prinsip jual beli, pembiayaan dengan prinsip sewa, pembiayaan dengan prinsip bagi hasil, dan pembiayaan dengan akad pelengkap. Oleh karena itu, dari uraian diatas penulis tertarik untuk melakukan penelitian lebih lanjut tentang Implementasi Produk Pembiayaan Usaha Mikro Kecil Menengah (UMKM) Pada PT. Bank Syariah Mandiri Cabang Pembantu Panyabungan.

Agar penelitian ini tidak keluar dari maksud yang ingin dicapai, maka penulis merumuskan penelitian ini tentang: "Bagaimana implementasi produk pembiayaan Usaha Mikro Kecil Menengah (UMKM) Pada PT. Bank Syariah Mandiri Cabang Pembantu Panyabungan?”. Dengan adanya penelitian ini diharapkan dapat diketahui bagaimana konsep dan pelaksanaan produk penyaluran dana oleh PT. Bank Syariah Mandiri Cabang Pembantu Panyabungan untuk Usaha Mikro Kecil Menengah (UMKM). Kemudian untuk mengetahui bagaimana strategi yang dilakukan dalam penyaluran produk pembiayaan Usaha Mikro Kecil Menengah di PT. Bank Syariah Mandiri Cabang Pembantu Panyabungan.

\section{TINJAUAN TEORITIK}

\section{Pembiayaan}

Pembiayaan merupakan aktivitas bank syariah dalam menyalurkan dana pihak lain selain bank berdasarkan prinsip syariah. Penyaluran dana dalam bentuk pembiayaan didasarkan pada kepercayaan yang diberikan oleh pemilik dana kepada pengguna dana. Pemilik dana 
percaya kepada penerima dana, bahwa dana dalam bentuk pembiayaan yang diberikan pasti akan dibayar. Penerima pembiayaan mendapat kepercayaan dari pemberi pembiayaan, sehingga penerima pembiayaan berkewajiban untuk mengembalikan pembiayaan yang telah diterima sesuai dengan jangka waktu yang telah diperjanjikan dalam akad pembiayaan (Ismail, 2011).

Menurut sistemnya penggunaannya, pembiayaan dapat di bagi menjadi 2 hal sebagai berikut:

1. Pembiayaan Produktif

Yaitu pembiayaan yang ditujukan untuk memenuhi kebutuhan produksi dalam arti luas, yaitu untuk peningkatan usaha, baik usaha produksi, perdagangan maupun investasi.

2. Pembiayaan konsumtif

Yaitu pembiayaan yang digunakan untuk memenuhi kebutuhan konsumsi, yang akan habis digunakan untuk memenuhi kebutuhan. Pembiayaan konsumtif diperlukan oleh pengguna dana untuk memenuhi kebutuhan tersebut.

Secara teknis bank memberikan pendanaan atau pembiayaan untuk mendukung atau berjalannya suatu usaha yang telah direncanakan kedua belah pihak dengan kesepakatan bagi hasil di dalamnya.

\section{Tujuan Dan Fungsi Pembiayaan}

Tujuan dari penyaluran pembiayaan dapat berupa (Hasibuan, 2009) :

1. Memperoleh pendapatan bank dari bagi hasil atau margin pembiayaan.

2. Memanfaatkan dan memproduksi dana-dana yang ada.

3. Melaksanakan kegiatan operasional bank.

4. Memenuhi permintaan dana dari masyarakat.

5. Memperlancar lalu lintas pembayaran.

6. Menambah modal kerja perusahaan/masyarakat.

7. Meningkatkan pendapatan dan kesejahteraan masyarakat.

Sedangkan manfaat pembiayaan adalah (Hasibuan, 2009) :

1. Menjadi motivator peningkatan kegiatan perdagangan dan perekonomian.

2. Memperluas lapangan kerja masyarakat.

3. Memperlancar arus barang dan arus uang.

4. Meningkatkan produktivitas dana yang ada.

5. Meningkatkan daya guna barang.

6. Meningkatkan kegairahan berusaha masyarakat.

7. Memperbesar modal kerja perusahaan.

8. Meningkatkan pendapatan masyarakat.

9. Mengendalikan harga.

10. Mengubah cara berfikir/bertindak masyarakat untuk lebih ekonomi. 


\section{Jenis - jenis Produk Pembiayaan UMKM}

Adapun jenis -jenis produk pembiayaan mikro yaitu (Nasution, 2017) :

1. Pembiayaan usaha mikro tunas

Pembiayaan mikro bank syariah yang sudah buka usaha 2 tahun untuk pembiayaan modal kerja, investasi, multiguna. Kemudian minimal pinjaman Rp. 2.000.00o (dua juta rupiah) dan maksismal Rp. 10.000.00o (sepuluh juta rupiah). Jangka waktu pembiayaan tersebut maksimal 3 tahun, biaya administrasi sesuai dengan ketentuan BSM atau $1 \%$.

2. Pembiayaan Mikro Madya

Pembiayaan mikro madya merupakan pembiyaan mikro dengan jumlah pinjaman Rp. 10.000.000 (sepuluh juta rupiah) sampai dengan Rp 50.000.000 (lima puluh juta rupiah). Jangka waktu maksimal 36 bulan/ 3 tahun, biaya administrasi sesuai ketentuan BSM atau $1 \%$.

3. Pembiayaan Mikro Utama

Pembiayaan mikro utama merupakan pembiayaan mikro dengan jumlah pinjaman Rp. 50.000.000 (lima puluh juta rupiah) sampai dengan Rp. 200.000.000 (dua ratus juta rupiah). Jangka waktu maksimal 60 bulan / 5 tahun, dan biaya administrasi sesuai dengan ketentuan BSM $1 \%$.

\section{Usaha Mikro Kecil Menengah (UMKM)}

Usaha kecil Merupakan kegiatan usaha yang mempunyai modal awal yang kecil, atau nilai kekayaan (aset) yang kecil dan jumlah pekerjaan yang juga kecil. Menurut UU No. 20 Tahun 2008 tentang UMKM dijelaskan bahwa Usaha Kecil Menengah adalah usaha ekonomi produktif yang berdiri sendiri yang dilakukan oleh orang perorangan atau badan usaha yang bukan merupakan anak perusahaan atau bukan cabang perusahaan yang dimiliki, dikuasai atau menjadi bagian langsung maupun tidak langsung dari usaha menengah atau usaha besar, yang memiliki kekayaan bersih lebih dari Rp. 50.000.000,oo, sampai dengan paling banyak Rp. 500.000.000,oo, tidak termasuk tanah dan bangunan tempat usaha, atau memiliki hasil penjualan tahunan lebih dari Rp. 300.000.000,o0, sampai dengan paling banyak Rp. 2.500.000.000,00.

\section{METODE PENELITIAN}

\section{Lokasi dan jenis Penelitian}

Lokasi penelitian ini PT. Bank Syariah Mandiri Cabang Pembantu Panyabungan, yang beralamat di Jln. Willem Iskandar No. 115 B, Panyabungan, Kabupaten Mandailing Natal, Sumatera Utara. Berdasarkan permasalahan yang terdapat dalam penelitian ini, 
maka penelitian ini menggunakan penelitian kualitatif dengan metode deskriptif. Penelitian kualitatif adalah penelitian yang dilakukan dengan mengamati fenomena di sekitarnya dan menganalisisnya dengan menggunakan logika ilmiah. Dalam hal ini peneliti berusaha menggambarkan dan menginterprestasikan objek sesuai dengan apa adanya (Arikunto, 2013).

\section{Informasi Penelitian}

Informasi penelitian adalah orang yang memberikan informasi tentang objek penelitiaan, guna pengumpulan data yang diperlukan dalam penelitian (Sugiyono, 2008). Informasi dalam penelitian ini adalah Karyawan divisi warung mikro PT. Bank syariah Mandiri KCP Panyabungan yaitu pelaksana marketing mikro dan admin pembiayaan mikro.

\section{Teknik Pengumpulan Dan Pengolahan Data}

Adapun instrumen pengumpulan data dalam penelitian ini adalah (Sugiyono,2012):

1. Observasi

Observasi adalah dasar semua ilmu pengetahuan. Para ilmuwan hanya dapat bekerja dengan berdasarkan data, yaitu fakta mengenai dunia kenyataan yang diperoleh melalui obsevasi. Observasi dilaksanakan untuk mengamati secara lagsung di lokasi penelitian tentang konsep dan aplikasi dari produk pembiayaan Usaha Mikro Kecil Menengah (UMKM), dan strategi apa saja yang harus dilakukan dalam mengembangkan produk pembiayaan Usaha Mikro Kecil Menengah (UMKM) di Bank Syariah Mandiri Cabang Pembantu Panyabungan.

2. Wawancara

Wawancara adalah percakapan dengan maksud tertentu. Percakapan itu dilakukan oleh dua belah pihak, yaitu pewawancara (interviewer) yang mengajukan pertanyaan dan yang diwawancarai (interviwee) yang memberikan jawaban atas pertanyaan itu. Pada penelitian ini peneliti melakukan wawancara dengan karyawan divisi warung mikro PT. Bank Syariah Mandiri KCP Panyabungan. Peneliti menggunakan jenis wawancara yang tidak tersturuktur artinya wawancara yang bebas dimana peneliti tidak menggunakan pedoman wawancara yang telah tersusun secara sistematis dan lengkap untuk pengumpulan datanya.

3. Dokumentasi

Dokumentasi adalah teknik pengumpulan data dengan mempelajari catatancatatan mengenai data pribadi, seperti yang dilakukan oleh seorang psikolog dalam meneliti perkembangan seorang klien melalui catatan pribadinya. Dalam penelitian ini penulis akan mencari data terkait dengan penelitian yang berupa catatan, 
transkrip, buku, surat kabar, majalah, agenda, dan sebagainya yang mendukung penelitian ini.

Analisis data adalah proses mengorganisasikan dan mengurutkan data ke dalam pola, hingga dapat ditemukan tema dan dapat dirumuskan hipotesis kerja yang disarankan oleh data (Moleong, 1999). Kemudian data diolah dengan model trianggulasi. Hal ini dilakukan dengan langkah-langkah yakni :

a. Reduksi data yaitu proses pemilihan pemusatan perhatian dan penyederhanaan, pengabstrakan dan transformasi dari data kasar yang muncul dari catatan-catatan di lapangan.

b. Penyajian data yaitu penyajian yang merupakan pemaparan sekumpulan data atau informasi tersusun yang memberikan kemungkinan adanya penarikan kesimpulan dan pengambilan tindakan.

c. Penarikan kesimpulan yaitu merupakan bagian dari suatu kegiatan konfigurasi yang utuh. Kesimpulan awal bersifat longgar dan akhir semakin rinci dan mengakar dengan kokoh. Apabila terjadi kesalahan data sehingga kesimpulan yang diambil kurang atau tidak sesuai maka dapat dilakukan proses ulang melalui tahapan yang sama.

\section{HASIL DAN PEMBAHASAN}

Pembiayaan warung mikro Bank Syariah Mandiri ini merupakan suatu produk alternatif yang diberikan oleh BSM kepada pengusaha yang memiliki keterbatasan modal dalam mengembangkan usahanya atau biasa disebut dengan UMKM ( Usaha Mikro Kecil Menengah). Pembiayaan Warung Mikro ini menggunakan akad murabahah. Adapun prosedur pembiayaan warung mikro Bank Syariah Mandiri adalah sebagai berikut:

1) Pertama-tama nasabah datang ke bank untuk mengajukan permohonan pembiayaan. Pihak pelaksana dan administrasi warung mikro akan melakukan pengecekan terhadap kelengkapan persyaratan yang telah diserahkan nasabah.

2) Setelah semua persyaratan terpenuhi, pihak bank akan melakukan analisis secara administratif dan bila diperlukan melakukan survey langsung kelapangan.

3) Selanjutnya Analisis Warung Mikro akan membuat proposal pembiayaan untuk diajukan kepada komite pembiayaan dan kepala cabang.

4) Bila proposal pembiayaan telah disetujui oleh komite pembiayaan dan kepala cabang maka selanjutnya bank melakukan akad/kontrak perjanjian dengan pihak nasabah.

5) Setelah akad dilakukan dengan nasabah maka bank akan mencairkan dana pembiayaan dengan mentransfer langsung pada rekening nasabah. 
6) Dengan akad wakalah bank menunjuk nasabah sebagai wakil dari bank untuk membeli barang yang dibutuhkan oleh nasabah (dalam hal kebutuhan untuk usaha) atas nama bank secarai tunai.

7) Ketika akad ditandatangani, maka kewajiban nasabah terhadap bank telah dimulai, yaitu membayar angsuran pembiayaan dengan besaran dan jangka waktu yang sudah disepakati dalam perjanjian.

Adapun persyaratan umum pembiayaan Warung Mikro yang harus dilengkapi nasabah adalah antara lain (Nasution, 2017):

1. Persyaratan permohonan pembiayaan bagi Wiraswasta/Profesional:

a. Pas foto terbaru suami/istri ukuran 3x4.

b. Fotokopi KTP/Paspor.

c. Fotokopi Kartu Keluarga (KK).

d. Fotokopi surat nikah suami dan istri.

e. Fotokopi Surat Keterangan Usaha (SKU).

f. Fotokopi rekening pembayaran listrik bulan terakhir.

g. Jaminan:

1) Sertikat, Akte Jual Beli.

2) Keterangan tidak tersengketa, Perjanjian jual beli.

3) BPKB Kendaraan.

h. Rencana Usaha dan Peruntukan Pembiayaan tercatat.

2. Persyaratan Permohonan Pembiayaan bagi Pengawai/Karyawan

a. Pas foto ukuran $3 \times 4$.

b. Fotokopi KTP/Paspor.

c. Fotokopi Kartu Keluarga (KK).

d. Fotokopi Surat Nikah dan surat permohonan suami \& istri.

e. Fotokopi Slip gaji + rekening, buku saldo tabungan terakhir.

f. Jaminan:

1) Sertifikat, jual beli.

2) Keterangan tidak bersengketa perjanjian jual beli.

3) ВРКB

g. Rencana Usaha dan Peruntukan Pembiayaan Tercatat.

3. Persyaratan untuk Badan Usaha:

a) Usaha telah berjalan minimal 2 tahun.

b) Surat keterangan/izin usaha.

c) Akte pendirian/perubahan perusahaan.

Adapun biaya yang dibebankan kepada nasabah UMKM dalam proses pengajuan pembiayaan warung mikro adalah (Lubis,2017) : 

a) Biaya asuransi jiwa
b) Biaya asuransi jaminan
c) Biaya notaris
d) Biaya administrasi
e) Biaya materai.

Dari uraian di atas secara garis besar tahapan yang akan dilalui oleh nasabah yang hendak mengajukan pembiayaan warung mikro adalah 4 (empat) tahap (Lubis,2017) :

1. Tahap permohonan pengajuan pembiayaan. Disini nasabah mengajukan jumlah pembiayaan yang diinginkan kepada bank. Setalah pengisian aplikasi permohonan, maka selanjutnya nasabah mengumpulkan kelengkapan data persyaratan pembiayaan

2. Tahap analisis yang dilakukan oleh bagian Analisis Warung Mikro yang ada di Bank Syariah Mandiri. Analisis yang dilakukan adalah 3 pilar analisis, yaitu kemampuan nasabah, aspek legalitas, dan objek akad. Analisis kemampuan dapat dilihat melalui fotokopi rekening tabungan (mutasi tabungan rekening perbulan), slip gaji, BI checking untuk mengetahui apakah calon nasabah memiliki pinjaman di bank lain atau tidak. Analisis legalitas data-data dapat diketahui melalui hasil wawancara dengan nasabah dan memverifikasi data-data calon nasabah yang sudah masuk, baik melalui telepon dan juga survey ke lapangan. Selain itu bank juga akan memeriksa melalui Sistem Informasi Debitur (SID) untuk mengetahui apakah calon nasabah masuk daftar hitam Bank Indonesia atau tidak.

3. Bila nasabah ada kekurangan persyaratan yang belum dilengkapi oleh nasabah, maka nasabah harus melengkapi persyaratan. Ketika semua persyaratan telah lengkap, maka pihak analisis warung mikro akan membuat proposal pembiayaan untuk dilaporkan kepada komite pembiayaan dan kepala cabang. Proposal tersebut nantinya akan dibawa ke rapat komite pembiayaan. Apabila komite pembiayaan beserta kepala cabang setuju, maka bisa dilanjutkan pada tahapan berikutnya.

4. Tahap terkakhir adalah melakukan akad antara pihak bank dan nasabah. Barulah setelah akad dilaksanakan dana pembiayaan akan langsung ditransfer oleh bank ke rekening nasabah. Sebelumnya nasabah tentunya telah melunasi biaya administrasi yang menjadi kewajiban pihak nasabah. Selanjutnya nasabah bisa menyetorkan angsuran pembayaran pertama sebulan setelah ditandatangani akad dengan cara menyetorkan angsuran perbulan sebesar yang telah disepakati dalam kontrak. 
Setiap produk yang diluncurkan ke nasabah tidak selalu mendapatkan respon yang positif. Bahkan cenderung mengalami kengagalan jauh lebih besar dibandingkan keberhasilan. Supaya produk yang diluncurkan berhasil sesuai dengan tujuan yang diharapkan, maka dalam peluncuran produk diperlukan strategi-strategi tertentu. Adapun Starategi PT. Bank Syariah Mandiri KCP Panyabungan dalam meningkatkan pembiayaan UMKM yang dilakukan adalah sebagai berikut (Lubis,2017) :

a. Melakukan Promosi

Salah satu upaya yang dilakukan oleh Bank Syariah Mandiri KCP Panyabungan dalam rangka meningkatkan pertumbuhan peningkatan pembiayaan UMKM adalah dengan melakukan promosi. Bukan hanya bagian marketing saja yang mempromosikan produk, akan tatapi seluruh karyawan ikut serta dalam mempromosikan produknya mulai dari satpam sampai pimpinan. Promosi yang dilakukan Bank Syariah Mandiri KCP Panyabungan adalah dengan memperkenalkan produknya dan masyarakat yang dituju adalah para pedangang kecil, dan grosir. Bukan hanya itu saja, bank memberikan hadiah kepada nasabah berupa tas, panyung dan pulpen.

b. Memberikan pelayanan yang baik

Pelayanan yang prima diberikan oleh bank kepada nasabah agar nasabah tetap nyaman ketika berhadapan dengan bank, dengan cara satpam selalu siap membuka pintu ketika nasabah datang, mengucapkan salam kepada nasabah, memberikan senyuman kepada nasabah, ramah dan sopan. Edukasi nasabah sesuai dengan kebutuhannya, memberika solusi dari setiap masalah keuangan nasabah yang terkait dengan bank.

c. Memberikan biaya yang relatif terjangkau ketika mengajukan pembiayaan

Biaya yang dibebankan kepada nasabah ketika mengajukan pembiayaan relatif lebih sedikti. Ketika nasabah mengajukan pembiayaan ke bank, semua berkas-berkas yang dibutuhkan sudah disediakan pihak bank seperti materai, asuransi jiwa, asuransi jaminan, dan notaris. Yang diperlukan dilengkapi nasabah persyaratan pengajuan pembiayaan. Maka wajar saja nasabah mengeluarkan biaya untuk kelancaran proses pencairan.

\section{KESIMPULAN}

Berdasarkan pemaparan yang telah dijelaskan oleh penulis pada bab-bab sebelumnya, maka ada beberapa kesimpulan yang dapat diambil sebagaimana berikut:

1. Pembiayaan Warung Mikro Bank Syariah Mandiri merupakan produk alternatif pembiayaan dari Bank Syariah Mandiri yang diperuntukkan bagi pengusaha yang skalanya sangat terbatas atau bisa disebut UMKM (Usaha Mikro Kecil Menengah) 
dengan menggunakan akad murabahah. Aplikasinya akad jual murabahah pada produk pembiayaan warung mikro dilakukan sebelum barang secara prinsip menjadi milik bank.

2. Strategi yang dilakukan dalam meningkatkan pembiayaan UMKM Pada Bank Syariah Mandiri antara lain:

a. Melakukan promosi.

b. Memberikan pelyanan yang baik

c. Memberikan biaya yang relatif sedikit kepada nasabah ketika mengajukan pembiayaan

\section{SARAN}

Merunjuk pada kesimpulan di atas maka penulis mencoba memberikan dan mengutarakan masukan atau rekomendasi bagi Bank Syariah Mandiri Cabang Pembantu Panyabungan yang kiranya dapat memberikan masukan kedepannya:

1. Menyesuaikan aplikasi produk pembiayaan yang memakai akad Murabahah dengan peraturan- peraturan yang ada seperti Fatwa Dewan Syariah Nasional dan peraturan Bank Indonesia. Dan mengedukasi nasabah sehingga nasabah tidak lagi merasa asing dengan keberadaan bank syariah.

2. Lebih memberdayakan masyarakat yang kurang mampu untuk dibina dalam meningkatkan usaha mikro mereka sehingga menjadi pengusaha yang sukses dan bertaqwa.

3. Sebagai salah satu bank syariah terbesar, tentunya Bank Syariah Mandiri harus lebih memperhatikan dan menjalankan prinsip-prinsip syariah agar tidak keluar dari koridor yang ada, sehingga akan menumbuhkan kesan yang baik di masyarakat.

\section{DAFTAR PUSTAKA}

Arikunto, Suharsimi, 2006, Prosedur Penelitian Suatu Pendekatan Praktik, Jakarta: PT. Rineka Cipta

Hasibuan, SP, Melayu, 2009, Dasar-dasar Perbankan, Jakarta:PT. Bumi Aksara

Ismail, 2011, Perbankan Syariah, Jakarta:Kencana

Moleong, J, Lexy, 1999, Metode Penelitian Kualitatif, Bandung:PT. Remaja Rosdakarya

Muhammad, 2005, Bank Syariah Proplem Dan Prospek Perkembangan Di Indonesia, Yogyakarta: Graha Ilmu

Sugiyono, 2008, Metode Penelitian Kuantitatif dan $R 7 B$, Bandung:Alfabeta , 2012, Metode Penelitian Bisnis, Bandung: Alfabeta 
Undang-Undang Republik Indonesia Nomor 21 Tahun 2008 tentang perbankan syariah. 2008. Jakarta: Kementerian Hukum dan HAM Republik Indionesia.

Wawancara dengan Bapak Damri Nasution sebagai Pelaksana Marketing Mikro di Bank Syariah Mandiri Cabang Pembantu Panyabungan.

Wawancara dengan Bapak Fauzi Abdullah Lubis sebagai Kepala Warung Mikro di Bank Syariah Mandiri Cabang Pembantu Panyabungan

Yaya, Rizal, dkk, 2009, Akuntasi Perbankan Syariah, Jakarta:Salemba Empat 